\title{
Ocena skutków regulacji zawartych w rządowym projekcie ustawy o grobach weteranów walk o wolność i niepodległość Polski (druk sejmowy nr 2902) ${ }^{1}$
}

\begin{abstract}
Impact assessment of rules the governmental Bill on Graves of Veterans of Struggles for the Independence and Sovereignty of Poland (Sejm's paper no. 2902): The bill aims at paying respect and remembrance to persons who died during a period of peace due to natural causes, but who took part in struggles for the independence and sovereignty of Poland. The bill envisages the creation of a collective record of graves of veterans of struggles for the independence and sovereignty of the Poland, carried out by the President of the Institute of National Remembrance, and the introduction of the system of a financial support for entities that take care for such graves. In the opinion of the author of the impact assessment, the procedure for making entries in the record of graves, and granting or refusing grants or pecuniary benefits should to be regulated in a more detailed way. It has a fragmentary character and does not contain any significant elements enabling the proper functioning of the procedure, which will significantly and permanently charge the state budget.
\end{abstract}

Keywords: state budget, grants, Institute of National Remembrance, impact assessment, bill

Słowa kluczowe: budżet państwa, dotacje, Instytut Pamięci Narodowej, ocena skutków regulacji, projekt ustawy

1 Opinia Ocena skutków regulacji zawartych w rządowym projekcie ustawy o grobach weteranów walk o wolność i niepodległość Polski (druk 2902) sporządzona 15 listopada 2018 r. na zlecenie zastępcy Szefa Kancelarii Sejmu; BAS-WASiE 2482/18. 


\section{Zakres przedmiotowy ustawy}

Przedmiotem opiniowanego projektu jest wprowadzenie regulacji prawnych określających zasady sprawowania opieki nad grobami weteranów walk o wolność i niepodległość Polski, tj. osób, które walczyły o odzyskanie niepodległości Polski lub w obronie niepodległości i granic suwerennej Polski, biorąc udział w wojnach, działaniach zbrojnych i niepodległościowych, działaniach zbrojnych w okresie od 1768 r. do 1963 r., oraz opieki nad grobami funkcjonariuszy cywilnych władz powstań narodowych, administracji podziemnego państwa polskiego w okresie II wojny światowej, członków władz i rządu Rzeczypospolitej Polskiej na uchodźstwie w latach 1939-1990, a także podziemnych niepodległościowych organizacji cywilnych w latach 1945-1956. Projekt oddziałuje na sektor finansów publicznych.

\section{Podmioty, na które oddziałuje projektowany akt}

Projekt dotyczy: Instytutu Pamięci Narodowej - Komisji Ścigania Zbrodni Przeciwko Narodowi Polskiemu (IPN), fundacji, organów władzy publicznej (w tym wojewodów), stowarzyszeń, kościołów lub związków wyznaniowych, innych osób prawnych oraz jednostek organizacyjnych niebędących osobami prawnymi, którym ustawa przyznaje zdolność prawną, które mają informacje o grobach weteranów walk o wolność i niepodległość Polski, a także osób fizycznych oraz konsulów Polski².

\section{Celowość wprowadzenia aktu}

Projekt ma na celu otoczenie szacunkiem i pamięcią osób, które zmarły w okresie pokoju z przyczyn naturalnych, ale brały udział w walce o wolność i niepodległość Polski, poprzez objęcie wsparciem finansowym i opieką właściwych instytucji państwowych indywidualnych grobów weteranów walk z okresu od 1768 r. do 1963 r., znajdujących się na terytorium Polski, jak i poza jej granicami. Projekt obejmuje także otoczenie opieką grobów weteranów, za których uznaje się również uczestników walk zbrojnych oraz funkcjonariuszy cywilnych rządów powstańczych i władz emigracyjnych. Konieczność uchwalenia opiniowanego projektu nie wynika z prawa UE ani z prawa międzynarodowego. W projekcie wskazano, że mierzenie efektów, w szczególności monitorowanie wykorzystania

Oddziaływanie projektu może być szersze. Przykładowo projekt może pośrednio oddziaływać na przedsiębiorców, zajmujących się m.in. zabiegami konserwatorskimi czy remontowo-kamieniarskimi. 
limitów wydatków przewidzianych na ten cel, ma spoczywać na Prezesie IPN. Określono również jego wpływ na sektor finansów publicznych w perspektywie 10 lat od wejścia projektu w życie, natomiast samo osiągnięcie celu projektu stanowić ma proces ciągły i nie jest określone w czasie.

\section{Planowane środki (narzędzia i działania) realizacji celów}

Cele wskazane $\mathrm{w}$ projekcie mają zostać osiągnięte przede wszystkim poprzez utworzenie zbiorczej ewidencji grobów weteranów walk o wolność i niepodległość Polski, którą prowadzić ma Prezes IPN, oraz wprowadzenie systemu finansowego wsparcia podmiotów sprawujących opiekę nad takimi grobami. Forma przyznania pomocy uzależniona ma być od tego, który podmiot ubiega się o jej otrzymanie. $W$ przypadku zwrócenia się o pomoc przez fundacje, stowarzyszenia, kościoły lub związki wyznaniowe, inne osoby prawne oraz jednostki organizacyjne niebędące osobami prawnymi, którym ustawa przyznaje osobowość prawną, uzyska ona formę dotacji celowej z budżetu państwa. Natomiast w przypadku ubiegania się o pomoc przez osoby fizyczne - formę świadczenia pieniężnego.

Projekt przewiduje również udostępnienie w Biuletynie Informacji Publicznej Instytutu Pamięci Narodowej wykazu grobów weteranów walk o wolność i niepodległość Polski.

W projekcie wskazano również, że koszty utrzymania oraz remontów grobów, wpisanych do ewidencji prowadzonej przez Prezesa IPN, ponoszone będą ze środków budżetu państwa. W pierwszym roku wejścia projektu w życie kwota 2,5 mln zł ma zostać pokryta z rezerwy ogólnej budżetu państwa, natomiast kwota wydatków w wysokości 2,775 mln zł zostanie sfinansowana w ramach budżetu państwa części 13 - Instytut Pamięci Narodowej - Komisja Ścigania Zbrodni przeciwko Narodowi Polskiemu. W latach kolejnych pomoc finansowana będzie ze środków określanych corocznie w ustawach budżetowych w ramach wydatków części 13. Wskazano ponadto, że wobec braku jakiejkolwiek wyjściowej ewidencji grobów weteranów określenie skali potrzeb oparto jedynie na przybliżonych szacunkach, oznacza to, że trudno jednoznacznie wskazać, czy planowane środki będą wystarczające do realizacji zakładanych celów.

\section{Ocena kosztów i korzyści}

\section{Skutki prawne}

Oceniając skutki prawne opiniowanego projektu, należy zauważyć, że zasadnicze wątpliwości budzić może rozwiązanie polegające na wyłączeniu stosowania przepisów ustawy - Kodeks postępowania administracyjnego (art. 11 projektu) w odniesieniu do rozpatrywania wniosków o wpis do ewidencji grobów wete- 
ranów walk o wolność i niepodległość Polski, wniosków o przyznanie dotacji celowej oraz wniosków o przyznanie świadczenia pieniężnego na sfinansowanie opieki i remontu miejsc spoczynku osób, o których mowa w art. 2 ust. 1 i ust. 2 projektu. W uzasadnieniu projektu nie wskazano powodów, dla których przepisy Kodeksu postępowania administracyjnego miałyby nie znajdować zastosowania w powyższym zakresie, tworząc tym samym pewien stopień niepewności u podmiotów ubiegających się o przyznanie dofinansowania bądź uzyskanie wpisu co do tego, w jaki sposób będzie kształtowała się ich sytuacja prawna oraz wedle jakich reguł będzie się toczyć postępowanie w tym obszarze.

W zakresie uregulowania trybu dokonywania wpisów do ewidencji grobów oraz przyznawania bądź odmowy przyznania dotacji czy świadczenia pieniężnego należy zauważyć, że mają one charakter szczątkowy i nie zawierają istotnych elementów umożliwiających odpowiednie funkcjonowanie procedury.

W pierwszej kolejności należy wskazać, że w projekcie nie uregulowano trybu, w jakim wnioskodawca może wnieść odwołanie w razie odmowy uznania przez Prezesa IPN danego grobu za grób weterana walk o wolność i niepodległość Polski. W szczególności nie wskazano charakteru odmowy (czy przyjmie ona postać decyzji, postanowienia itp.), terminu, w jakim odwołanie przysługuje, elementów, jakie winno zawierać, nie wskazano również terminu, w jakim Kolegium IPN (do którego wnosi się odwołanie) zobowiązane będzie do jego rozpatrzenia. Projektodawca nie wskazał ponadto, w jakiej formie ma nastąpić poinformowanie wnioskodawcy o pozytywnym rozpatrzeniu wniosku i dokonaniu wpisu. W uzasadnieniu projektu nie wyjaśniono również, z jakich powodów, w przypadku grobu znajdującego się poza terytorium Polski, osoby fizyczne nie mogą wnioskować o dokonanie takiego wpisu (w świetle projektu wpis do ewidencji takiego grobu możliwy jest jedynie na wniosek konsula Polski lub z urzędu).

Na uwagę zasługuje również okoliczność, że z projektu nie wynika wprost, do jakiego organu IPN należy skierować wniosek o udzielenie dotacji celowej z budżetu państwa, wskazano jedynie, że „dotacja może być udzielona przez Instytut” (art. 8 ust. 3 projektu). Jak wynika z art. 8 ust. 7 projektu, „wniosek o udzielenie dotacji rozpatruje się w terminie 3 miesięcy od dnia jego otrzymania”, jednak nie jest jasne, na którym organie IPN będzie spoczywał obowiązek rozpatrzenia wniosków ani w jakiej formie należy przekazać ów wniosek do Instytutu (elektronicznej, tradycyjnej pocztowej). Podobnie w przypadku ubiegania się o przyznanie świadczenia pieniężnego przez osobę fizyczną. Co więcej, projektodawca nie przewidział również, jaką formę powinna przyjąć odmowa udzielenia dotacji czy przyznania świadczenia pieniężnego na realizację celów (decyzja, postanowienie), o których mowa w projekcie, i czy wnioskodawcy przysługują w tym zakresie jakiekolwiek środki odwoławcze.

Wątpliwości może budzić także pominięcie w treści projektowanego art. 9 ust. 1 kryteriów różnicujących sytuację, w której osoba fizyczna może ubiegać się o przyznanie przez IPN świadczenia pieniężnego na pokrycie całości kosz- 
tów opieki nad miejscami spoczynku, oraz sytuację, gdy osoba fizyczna otrzyma środki na sfinansowanie jedynie części kosztów sprawowanej opieki. Nie wskazano ponadto o pokryciu jakiej części wydatków z budżetu państwa można się ubiegać (czy będzie to przykładowo 50\% czy 80\%).

\section{Skutki finansowe}

Opiniując projekt pod względem skutków finansowych, należy wskazać, że jego wejście w życie wiąże się z wydatkami, które w sposób istotny i ciągły obciążą budżet państwa. Uwzględniając szacunki przyjęte przez projektodawcę, tj. średni koszt remontu nagrobka (7000 zł) oraz ich przybliżoną liczbę (ok. 200000 grobów weteranów), realizacja projektu oznacza wydatki na opiekę i remont miejsc spoczynku w łącznej kwocie $1 \mathrm{mld} 400 \mathrm{mln}$ zł (bez uwzględnienia kosztów pracowniczych i wdrożenia systemu opieki nad grobami).

Jak wynika z uzasadnienia projektu, dla realizacji zakładanych celów konieczne będzie m.in. zwiększenie kosztów organizacyjnych oraz zatrudnienie nowych pracowników (planuje się zatrudnienie ok. 25 dodatkowych pracowników koszt roczny ok. 1625000 zł) i zapewnienie im warunków do pracy, w tym wyposażenie stanowisk pracy w biurowe urządzenia eksploatacyjne, meble, sprzęt komputerowy, przeszkolenie pracowników. Mimo że z treści projektu nie wynika wprost, w jakiej formie IPN miałby utworzyć ewidencję grobów weteranów walk o wolność i niepodległość Polski, z uzasadnienia wywnioskować można, że byłaby to forma elektroniczna, ponieważ przewidziano również wydatki na zakup aplikacji i oprogramowania dla obsługi ewidencji grobów w wysokości ok. 40000 zł. Uwzględniając powyższe wydatki, środki przeznaczone w budżecie państwa na realizację bezpośredniego celu projektu - tj. utrzymanie, remont i opiekę nad grobami weteranów, mają pozwolić na opiekę nad ok. 520 grobami rocznie. $\mathrm{W}$ tym miejscu należy jednak wskazać, że koszty remontu nagrobków przyjęte przez projektodawcę w wysokości ok. 7000 zł mogą poważnie wzrosnąć w odniesieniu do tych nagrobków, które znajdują się za granicą (wówczas wydatki te mogą zwiększyć się co najmniej kilkukrotnie), a także w stosunku do tych nagrobków, które zostały objęte opieką konserwatorską (wówczas z uwagi na nakład pracy konserwatora zabytków koszt remontu może oscylować od kilku do nawet kilkudziesięciu tysięcy złotych). Nie można zatem wykluczyć, że przewidziane w projekcie środki na realizację zakładanych celów w praktyce nie wystarczą na pokrycie kosztów opieki nad grobami w zaplanowanej wysokości.

Ponadto, jak wynika $\mathrm{z}$ treści projektu świadczenie pieniężne przyznawane osobom fizycznym sprawującym opiekę nad grobami weteranów walk o wolność i niepodległość Polski będzie korzystało m.in. ze zwolnienia z podatku dochodowego od osób fizycznych (art. 12 projektu). Przyjęte rozwiązanie nie budzi poważniejszych wątpliwości, ponieważ na gruncie ustawy o podatku dochodowym od osób fizycznych znane są już zwolnienia także innych świadczeń otrzymywanych przez osoby biorące udział w walkach w obronie wolności i niepodległości 
Polski. Jako przykład można przytoczyć zwolnienie dodatku kompensacyjnego przyznanego na podstawie ustawy o kombatantach oraz niektórych osobach będących ofiarami represji wojennych i okresu powojennego (art. 21 ust. 1 pkt 25a ustawy o podatku dochodowym od osób fizycznych), odszkodowania lub zadośćuczynienia otrzymanego na podstawie przepisów o uznaniu za nieważne orzeczeń wydanych wobec osób represjonowanych za działalność na rzecz niepodległego bytu państwa polskiego (art. 21 ust. 1 pkt 3a ustawy o podatku dochodowym od osób fizycznych) czy rent przyznawanych na podstawie przepisów o zaopatrzeniu inwalidów wojennych i wojskowych oraz ich rodzin (art. 21 ust. 1 pkt 2 ustawy o podatku dochodowym od osób fizycznych). Niniejszy projekt w swoim ostatecznym kształcie nie pozostawia również wątpliwości co do tego, że dotacja celowa przyznana $\mathrm{z}$ budżetu państwa na realizację zakładanych celów mieści się w definicji zwolnienia określonego w art. 17 ust. 1 pkt 47 ustawy o podatku dochodowym od osób prawnych.

\section{Skutki społeczne}

Objęcie opieką państwa grobów osób walczących o wolność i niepodległość Polski może wywołać pozytywny odbiór społeczny w postaci zwiększenia świadomości historycznej społeczeństwa i poczucia patriotyzmu.

Niemniej należy zauważyć, że w projekcie nie została wskazana procedura rozdysponowania środków przeznaczonych na utrzymanie i remonty grobów weteranów, w szczególności nie wskazano limitów przyznanych środków oraz tego, w jaki sposób i jak często będzie dokonywana ocena stanu miejsca pochówku, a także jakie kryteria zadecydują o tym, na które ze zgłoszonych miejsc pochówku zostaną przyznane środki finansowe w pierwszej kolejności w sytuacji wyczerpania puli środków przewidzianych na dany rok.

\section{Skutki administracyjno-organizacyjne}

Wejście w życie projektu spowoduje wyposażenie Prezesa IPN oraz pracowników IPN w dodatkowe kompetencje w zakresie ewidencjonowania miejsc spoczynku weteranów walk o wolność i niepodległość Polski, badania ich istnienia w kraju i za granicą, a także przyznawania środków finansowych na utrzymanie i remonty grobów. Powyższe skutkuje koniecznością zatrudnienia dodatkowych pracowników (przewiduje się zatrudnienie ok. 25 pracowników w IPN), a także zapewnienia im odpowiednich warunków wykonywania pracy, w tym zaplecza lokalowego. Projekt nakłada również na IPN dosyć niejasny obowiązek współpracy z organami władzy publicznej, fundacjami, stowarzyszeniami, instytucjami społecznymi, kościołami i związkami wyznaniowymi i innymi podmiotami, posiadającymi informacje o miejscach spoczynku weteranów, w celu pozyskiwania danych i informacji służących badaniu, czy dany grób spełnia kryteria uznania go za grób weterana walk o wolność i niepodległość Polski. W projekcie nie określono bowiem, na czym owa współpraca miałaby polegać i w jaki sposób przebiegać. 
Wprowadzenie zmian przewidzianych w projekcie spowoduje również konieczność utworzenia nowej struktury danych w postaci ewidencji grobów weteranów walk o wolność i niepodległość Polski oraz zapewnienia jej stałego funkcjonowania.

\section{Podsumowanie - ogólna ocena projektu}

Projektowana regulacja realizować będzie cel, jaki projektodawca przed nią postawił, a mianowicie w sposób istotny przyczyni się do zachowania i otoczenia należytą opieką miejsc spoczynku weteranów walk o wolność i niepodległość Polski. Prezentowana w projekcie idea może również przyczynić się do zwiększenia świadomości historycznej społeczeństwa. Należy jednak mieć na uwadze, że wejście projektowanej ustawy w życie związane jest $\mathrm{z}$ istotnym i w zasadzie stałym obciążeniem budżetu państwa wydatkami ponad $5 \mathrm{mln}$ zł rocznie. Ponadto uszczegółowienia wymagają zwłaszcza regulacje dotyczące trybu dokonywania wpisów do ewidencji grobów oraz przyznawania bądź odmowy przyznania dotacji czy świadczenia pieniężnego, które w projektowanym kształcie mają charakter jedynie fragmentaryczny i nie zawierają istotnych elementów umożliwiających odpowiednie funkcjonowanie procedury. Warto byłoby zatem rozważyć uszczegółowienie projektu we wskazanym zakresie. 